\title{
Dampak Pemutusan Hubungan Kerja di Masa Pandemi Covid-19 terhadap Ketahanan Keluarga
}

\author{
Nabila Luthvita Rahhma1, Anisa Yuniar2, Fatimah Qurrotu A'yun', \\ Indri Kurniati ${ }^{4}$, Dania Saferina Ifada ${ }^{5}$ \\ IAIN Kudus', IAIN Kudus' ${ }^{2}$, IAIN Kudus ${ }^{3}$, IAIN Kudus ${ }^{4}$, IAIN Kudus ${ }^{5}$ \\ nabilalr@iainkudus.ac.id
}

\begin{abstract}
The purpose of this study was to determine the impact of termination of employment during the Covid-19 pandemic on family resilience. This study uses a case approach and a law approach with primary legal sources and secondary legal sources in the form of books or legal journals related to the research title. The results of this study indicate that the termination of employment experienced by the head of the family or family member during the Covid-19 pandemic did not significantly affect family resilience, as evidenced by the divorce rate which did not increase significantly and was not caused by termination of employment. As for maintaining family resilience during the Covid-19 pandemic can be done by carrying out the rights and obligations of each family member in accordance with the study of Islamic family law, in addition to maintaining interpersonal communication between family members.
\end{abstract}

Keywords: Termination of Employment, Covid-19 Pandemic, Family Resilience

\begin{abstract}
Abstrak
Tujuan dari penelitian ini adalah untuk mengetahui dampak dari Pemutusan Hubungan Kerja pada masa pandemi Covid-19 terhadap ketahanan keluarga. penelitian ini menggunakan metode pendekatan kasus dan pendekatan undang undang dengan sumber hukum primer dan sumber hukum sekunder berupa buku atau jurnal jurnal hukum berkaitan dengan judul penelitian. Hasil dari penelitian ini menunjukkan jika Pemutusan Hubungan Kerja yang dialami kepala keluarga atau anggota keluarga pada masa pandemi Covid-19 tidak terlalu berpengaruh terhadap ketahanan keluarga dibuktikan dengan angka perceraian yang tidak naik signifikan dan tidak disebabkan oleh pemutusan hubungan kerja. Adpaun untuk menjaga ketahanan keluarga di masa pandemi Covid-19 dapat dilakukan dengan melakukan hak dan kewajiban masing masing anggota keluarga sesuai dengan kajian hukum keluarga islam, disamping menjaga komunikasi interpersonal antar sesama anggota keluarga.
\end{abstract}

Kata Kunci: Pemutusan Hubungan Kerja, Pandemi Covid-19, Ketahanan Keluarga

\section{PENDAHULUAN}

Merujuk dari permasalahan berdasarkan aspek keutuhan keluarga apakah ada pengaruh atau dampak dari Covid-19. Maka pada masa pandemi menjadikan stabilitas keluarga menjadi goyah. Hal tersebut disebabkan antara lain dampak Covid-19 adalah kehilangan pekerjaan bagi kepala keluarga. Kehilangan pekerjaan kerap kali menghasilkan duka, sektor ekonomi yang mulai terguncang membuat kesehatan mental sebagian 
Nabila Luthvita Rahhma, Anisa Yuniar, Fatimah Qurrotu A'yun, Indri Kurniati, Dania Saferina Ifada

keluarga terganggu, terutama mereka yang berada dikelas menengah kebawah.

Penyebab dari sebuah perusahan melakukan pemutusan hubungan kerja pada masa pandemi saat ini merujuk pada pernyataan Wakil Ketua Umum Kadin, yang dikarenakan lemahnya permintaan pasar suatu perusaahan yang diakibatkan adanya kebijakan Pembatasan Sosial Berskala Besar (PSBB), adanya keterbatasan bantuan modal, dan keterbatasan cash-flow terutama untuk membiayai gaji tenaga kerja yang merupakan komponen tertinggi dari biaya perusahaan.

Pemutusan Hubungan Kerja, sebagaimana diatur dalam Pasal 156 Ayat (1) Undang-Undang Nomor 13 Tahun 2003 Tentang Ketenagakerjaan, terdiri dari uang pesangon dan atau penghargaan masa kerja dan uang pengganti hak yang seharusnya diterima, artinya penetuan uang kompensasi sering menjadi kompleks karena terjadi perbedaan pendapat, sehingga pekerja cendrung menuntut kompensasi yang lebih tinggi sementara pengusaha memilih kompensasi yang lebih rendah. Artinya terdapat perbedaan kepentingan termasuk perbedaan presepsi tentang uang pesangon dari pihak pengusaha dan pekerja sehingga besar pemberian uang pesangon menjadi bahan perselisihan Sehingga diperlukan upaya reformulasi konsep uang pesangon.

Mengatasi persoalan tersebut, Pemerintah melalui kementrian ketenagakerjaan menerbitkan Surat Edaran Mentri Ketenagakerjaan Nomor M/3/HK.04/III/2020 Tentang Perlindungan Pekerja atau Buruh dan Kelangsungan Usaha dalam Rangka Pencegahan dan Penanggulangan COVID-19. Selain itu Persiden juga membuat kebijakaan yang diatur dalam Perpres Nomor 36 Tahun 2020 memuat tentang implementasi program kartu prakerja untuk mengantisipasi PHK akibat wabah virus corona di Indonesia, yang saat ini sudah di ubah ke dalam Perpres Nomor 76 Tahun 2020.

Selain ekonomi, aspek lain juga terdampak seperti halnya aspek sosial, aspek psikologis dan spiritual yang dapat dirasakan dampaknya. Sebagian besar masyarakat menahan diri untuk tidak beraktivitas diluar dan berbagai bentuk kegiatan sementara ini dihilangkan. Dengan menghadapi situasi dampak pandemi ini, keluarga sebagai tumpuan solusi dalam menghadapi pandemi Covid-19 merupakan sumber pertolongan pertama bagi anggota keluarganya. Memelihara kesehatan dan kekuatan keluarga dalam memfungsikan kembali fungsi keluarga merupakan aspek penting yang harus dipelihara. Dengan adanya ketahanan keluarga akan membangkitkan motivasi anggota keluarga dalam menghadapi situasi krisis dimasa pandemi Covid-19 saat ini. 


\section{METODE PENELITIAN}

Penelitian ini menggunakan metode yuridis normative, dengan menggunakan pendekatan undang undang, dan pendekatan kasus. Pendekatan perundang-undangan adalah pendekatan yang dilakukan dengan menelaah semua peraturan perundang-undangan dan regulasi yang bersangkut paut dengan isu hukum yang ditangani (Peter Machmud, 2011: 93). Pendekatan penelitian menggunakan argumentasi hukum dalam perspektif kasus konkrit yang terjadi dilapangan, yaitu kasus yang berkaitan dengan kasus atau peristiwa hukum yang terjadi di lapangan. Penelitian ini membutuhkan data primer berupa peraturan perundang-undangan yang bersangkut paut dengan permasalahan Pemutusan Hubungan Kerja, dan Ketahanan Keluarga yang berlandaskan pada aturan pemerintah dan Kompilasi Hukum Islam. Disamping, sumber hukum sekunder berupa artikel jurnal maupun buku yang penulis butuhkan dalam memecahkan isu hukum yang terdapat dalam tulisan ini. Setelah data terkumpul, hasil penelitian dituangkan dan dianalisa dalam bentuf deskriptif dengen metode induktif yaitu daru umum ke khusus untuk selanjutnya dapat diketemukan hasil dan ditarik kesimpulan

\section{PEMBAHASAN}

\section{Dampak PHK Terhadap Ketahanan Keluarga Dimasa Pandemi}

Dalam dinamika ketenagakerjaan di Indonesia, hubungan kerja tidak serta merta berjalan dengan optimal atau dapat dikatakan mengalami permasalahan yang bisa disebabkan oleh si pekerja ataupun perusahaan. Diantara pekerja yang merasa dirugikan dengan kebijakan dari perusahaan, maupun perusahaan yang merasa dirugikan dengan kelalaian para pekerja. Dari faktor tersebut, maka dapat memungkinkan adanya perselisihan antara pekerja dan pengusaha dalam hal Pemutusan Hubungan Kerja (PHK) ditambah dengan adanya pandemi Covid-19 yang telah menyebar keseluruh dunia termasuk Indonesia. Sehingga, beberapa perusahaan mengeluarkan kebijakan untuk memutus hubungan kerja dengan beberapa pekerja yang dirasa mengakibatkan menambah kerugian perusahaan.

Berdasarkan data yang dilansir dari Kementrian Ketenagakerjaan, terdapat 2,8 juta pekerja yang terkena dampak langsung akibat Covid-19. Mereka terdiri dari 1,7 juta pekerja formal dirumahkan dan 749,4 ribu di PHK (ketenagakerjaan). Namun naasnya perusahaan yang memutus hubungan bekerja berdalih dengan alasan "force majeure". Alasan tersebut menjadi perdebatan di kalangan para pekerja maupun ahli yang mempermasalahkan alasan force majeure bisa diterima atau tidak dalam memutus hubungan kerja dimasa pandemi Covid-19 (Juaningsih, 2020:192193). 
Nabila Luthvita Rahhma, Anisa Yuniar, Fatimah Qurrotu A'yun, Indri Kurniati, Dania Saferina Ifada

Gelombang PHK naik signifikan selama 9 bulan terakhir. Pada masa pandemi Covid-19 umumnya pemutusan hubungan kerja (PHK) karena alasan force majeure (keadaan memaksa) dan efisiensi. Dampak pandemi Covid-19, selain pekerja di-PHK, Sebagian pekerja "dirumahkan", pemutusan kontrak kerja sebelum berakhir, pemotongan upah, hingga memberlakukan prinsip no work no pay (Muslim, 2020 : 357).

Pandemi Covid-19 yang mulai masuk Indonesia pada awal bulan maret 2020 tentu membawa pengaruh terhadap segala sendi kehidupan masyarakat termasuk di dalamnya segi rumah tangga. Dampak dari pandemi Covid-19 yang berkepanjangan dalam kehidupan berumah tangga sangat berpengaruh terutama dalam hal pendapatan dan perekonomian masing-masing rumah tangga. Banyak kepala keluarga yang di PHK pada masa pandemi ini membawa pengaruh terhadap keuangan rumah tangga menjadi bermasalah seperti pemasukan yang berkurang atau bahkan hilang sama sekali. Sehingga menimbulkan permasalahan di dalam rumah tangga yang tidak menutup kemungkinan terjadinya perceraian.

Rancangan Undang Undang tentang Ketahanan Keluarga menyebutkan, Ketahanan Keluarga adalah kondisi dinamik keluarga dalam mengelola sumber daya fisik maupun non fisik dan mengelola masalah yang dihadapi, untuk mencapai tujuan yaitu keluarga berkualitas dan tangguh sebagai pondasi utama dalam mewujudkan Ketahanan Nasional.

Perhatian terhadap pentingnya ketahanan keluarga termaktub dalam Undang-Undang No 52 tahun 2009 (perubahan UU No 10 Tahun 1992) tentang perkembangan kependudukan dan pembangunan keluarga yang di dalamnya mendeinisikan ketahanan (dan kesejahteraan) keluarga sebagai "kondisi dinamik suatu keluarga yang memiliki keuletan dan ketangguhan serta mengandung kemampuan isik-materiil dan psikismental spiritual guna hidup mandiri dan mengembangkan diri dan keluarganya untuk hidup harmonis dalam meningkatkan kesejahteraan lahir dan kebahagian batin." (Euis, 2015; 5).

Menurut data Mahkamah Agung, pada masa pandemi angka perceraian anjlok menjadi 16.410 pada April dan 11.848 pada Mei, dari 33.999 kasus pada Maret sebelum penerapan PSBB dibanyak daerah. Ketika PSBB dicabut pada Juni, angka perceraian melonjak menjadi 57.750 kasus, 51.133 pada Juli, dan 36.525 pada Agustus. Seperempat perceraian ini dilatarbelakangi masalah ekonomi (Sucahyo, 2021). 
Dampak Pemutusan Hubungan Kerja Di Masa Pandemi Covid-19 Terhadap Ketahanan Keluarga

Data Perceraian tahun 2020 menurut data Mahkamah Agung.

\begin{tabular}{|l|c|c|c|}
\hline Bulan & Gugat Cerai & Cerai Talak & Total \\
\hline Januari & 43.508 & 15.046 & 58.554 \\
\hline Februari & 29.819 & 10.653 & 40.472 \\
\hline Maret & 25.107 & 8.892 & 33.999 \\
\hline April & 16.410 & 4.584 & 16.410 \\
\hline Mei & 8.564 & 3.284 & 11.848 \\
\hline Juni & 43.445 & 14.305 & 57.750 \\
\hline Juli & 38.568 & 12.565 & 51.133 \\
\hline Agustus & 27.406 & 9.119 & 36.525 \\
\hline
\end{tabular}

Kenaikan signifikan angka perceraian pada bulan Juni dan Juli 2020, memang tidak melulu disebabkan oleh pandemi Covid-19. Direktur Jenderal Badan Peradilan Agama Mahkamah Agung, Aco Nur membantah kasus perceraian di Indonesia melonjak drastis di masa pandemi Covid-19. Aco mengatakan bahwa dampak pandemi Covid-19 pada kasus perceraian tidak signifikan dengan jumlah perkara perceraian yang dipicu oleh masalah-masalah yang muncul akibat pandemi hanya sekitar dua persen dari total perkara yang masuk ke pengadilan. Menurut Aco, perkara perceraian yang masuk ke pengadilan sepanjang JanuariAgustus 2020 lebih banyak disebabkan oleh perselisihan dan pertengkaran terus menerus pasangan suami istri, faktor ekonomi, dan satu pihak meninggalkan pihak yang lain.

Sekalipun tidak banyak, namun berdasarkan data dan pernyataan diatas, pandemi Covid-19 beserta dampak ekonomi berupa PHK kepada kepala keluarga membawa pengaruh terhadap ketahanan keluarga. Dimasa pandemi saat ini ketahanan keluarga sangat diperlukan sehingga keluarga tetap utuh dan kuat. Hal tersebut dipelrukan agar beban anggota keluarga yang sedang patah semangat akibat dampak pandemi Covid-19 ini terasa ringan. Dari dampak pandemi saat ini dukungan keluarga sangat diperlukan untuk mengembalikan semangat anggota keluarganya dalam menghadapi masa pandemi saat ini. Ketahanan Keluarga yang diharapkan mampu melewati segala ujian di tengah pandemi Covid-19 rupanya harus tumbang dan berakhir di meja hijau.

\section{Upaya Dalam Menjaga Keutuhan Keluarga di Masa Pandemi Covid-19}

Keluarga memiliki berbagai fungsi penting yang menentukan kualitas kehidupan baik kehidupan individu, keluarga, bahkan kehidupan sosial (kemasyarakatan). Fungsi keluarga dapat dibagi menjadi fungsi ekspresif dan instrumental. Fungsi ekspresif keluarga berkaitan dengan pemenuhan kebutuhan emosi dan perkembangan, termasuk moral, loyalitas, dan sosialisasi anak. Sementara itu fungsi instrumental berkaitan dengan 
Nabila Luthvita Rahhma, Anisa Yuniar, Fatimah Qurrotu A'yun, Indri Kurniati, Dania Saferina Ifada

perolehan sumberdaya ekonomi dan manajemen untuk mencapai berbagai tujuan keluarga.

Sementara itu, menurut Badan Koordinasi Keluarga Berencana Nasional (BKKBN), sejalan dengan Peraturan Pemerintah Nomor 21 tahun 1994, fungsi keluarga meliputi :

1. Fungsi keagamaan yaitu dengan memperkenalkan dan mengajak anak dan anggota keluarga yang lain dalam kehidupan beragama, dan tugas kepala keluarga untuk menanamkan keimanan bahwa ada kekuatan lain yang mengatur kehidupan ini dan ada kehidupan lain setelah di dunia ini.

2. Fungsi social budaya, dilakukan dengan membina sosialisasi pada anak, membentuk norma norma tingkah laku sesuai dengan tingkat perkembangan anak, meneruskan nilai nilai budaya keluarga.

3. Fungsi cinta kasih, diberikan dalam bentuk memberikan kasih sayang dan rasa aman, serta memberikan perhatian di antara anggota.

4. Fungsi melindungi, bertujuan untuk melindungi anak dari tindakan tindakan yang tidak baik, sehingga anggota keluarga merasa terlindungi dan merasa aman.

5. Fungsi reproduksi, merupaan fungsi yang bertujuan untuk meneruskan keturunan, memelihara dan membesarkan anak, memelihara dan merawat anggota keluarga.

6. Fungsi sosialisasi dan pendidikan, merupakan fungsi dalam keluarga yang dilakukan dengan cara mendidik anak sesuai dengan tingkat perkembangannya, dan menyekolahkan anak. Sosialisasi dalam keluarga juga dilakukan untuk mempersiapkan anak menjadi anggota masyarakat yang baik.

7. Fungsi ekonomi, adalah serangkaian dari fungsi lain yang tidak dapat dipisahkan dari sebuah keluarga. fungsi ini dilakukan dengan cara mencari sumber sumber penghasilan untuk memenuhi kebutuhan keluarga, pengatura penggunaan penghasilan keluarga untuk memenuhi kebutuhan keluarga, dan menabung untuk memenuhi kebutuhan keluarga di masa datang.

8. Fungsi pembinaan lingkungan.

Keberfungsian keluarga berlangsung sepanjang kehidupannya. Keluarga memiliki tugas perkembangan untuk menjaga keberlangsungan dan keberlanjutan kehidupan umat manusia (Euis, 2015; 8). Tugas tersebut adalah;

1. Pemeliharaan kebutuhan isik,

2. Alokasi sumber daya,

3. Pembagian tugas,

4. Sosialisasi anggota keluarga,

5. Reproduksi, penambahan dan pelepasan anggota keluarga,

6. Pemeliharaan tata tertib, 
7. Penempatan anggota di masyarakat luas, dan

8. Pemeliharaan moral dan motivasi.

Kemampuan membangun ketahanan menjadi suatu hal yang harus bisa diupayakan. Mengingat ketahanan keluarga merupakan kondisi dinamis suatu keluarga yang memiliki ketangguhan dan keuletan secara fisik, psikis, mental dan spiritual sehingga mampu mewujudkan kehidupan yang mandiri, mengembangkan diri dan keluarganya sehingga terbangun kelurga yang harmonis, sejahtera lahir dan batin.

Ketahanan keluarga sangat dibutuhkan disaat situasi seperti sekarang ini, yakni situasi darurat akibat pandemi Covid-19. Diperlukan suatu upaya strategis untuk meningkatkan ketahanan keluarga, agar masyarakat mampu bertahan hidup dan menjalankan tugas-tugas kehidupan sebagaimana mestinya. Keluarga merupakan tempat pertama bagi anggota keluarga seperti halnya suami istri maupun anak-anaknya untuk melepas keluh kesahnya dari dampak yang dihadapi saat ini yang cukup rentan menimbulkan stres.

Membangun ketahanan keluarga, yang pertama perlu dilakukan adalah mencegah terjadiya perceraian di dalam perkawinan. Perkawinan membawa perkembangan dan dinamika psikologi yang berbeda baik bagi suami maupun istri (Hana, 2020). Perkawinan juga memiliki masalah rumah tangga yang beragam dan tidak selalu sama dengan rumah tangga yang lain. hal itu sedikit banyak membuat kehidupan rumah tangga berjalan tidak selalu langgeng dan baik. Bagi pasangan yang tidak mampu menghadapi dan menyelesaikan masalah rumah tangga yang beragam tadi, tidak menutup kemungkinan rumah tangga tersebut akan retak dan berakhir dengan perceraian sebagai pintu darurat. Oleh karenanya diperlukan pola pola khusus untuk mengatasi permasalahan dalam rumah tangga.

Menurut Goode (Goode, 2009), ada beberapa pola untuk mencegah terjadinya perceraian. Keempat pola tersebut adalah :

1. Pola pertama adalah dengan cara merendahkan atau menekan keinginan-keinginan individu tentang apa yang bisa diharapkan dari sebuah perkawinan.

2. Pola kedua adalah dengan cara menanamkan nilai yang tidak mementingkan hubungan kekerabatan daripada hubungan suami-istri dalam perkawinan. Biasanya pada sistem keluarga yang demikian, anak laki-laki terutama memegang peranan sangat penting. Dialah yang mengendalikan kehidupan keluarga luas.

3. Pola ketiga adalah dengan cara tidak menganggap penting sebuah perselisihan.

4. Pola keempat adalah mengajarkan anak-anak dan para remaja untuk mempunyai harapan yang sama terhadap sebuah perkawinan. 
Nabila Luthvita Rahhma, Anisa Yuniar, Fatimah Qurrotu A'yun, Indri Kurniati, Dania Saferina Ifada

Sehingga dalam perkawinan nanti, seorang suami atau istri dapat berperan sesuai dengan yang diharapkan oleh pasangannya.

Selain empat pola diatas, agar terhindar dari keretakan dalam rumah tangga dapat dilakukan dengan cara sebisa mungkin untuk memberi ruang ke dalam hubungan sebaik yang dapat dilakukan. Misalnya dengan bekerja dari kamar yang berbeda, salah satu dari pasangan pergi berjalanjalan terpisah keluar atau melakukan aktivitas kesukaan yang berbeda. Selain itu hal untuk kesehatan mental pasangan, atur rutinitas sehari-hari dengan memasukkan waktu yang berisi hal-hal yang biasanya dilakukan, seperti mengatur waktu makan, olahraga harian, waktu sendiri, dan waktu bersama. (Adi, $2020: 88$ ).

Dalam koridor hukum Islam, kajian hukum keluarga Islam disebut al ahwal al syakhsiyyah. Al ahwal al syakhsiyyah adalah hubungan hukum yang timbul antar individu individu dalam keluarga yang dimulai dari perkawinan sampai berakhirnya perkawinan. Baik putusnya hubungan perkawinan karena meninggal duni atau karena erceraian. Adapun al ahwal al syakhsiyyah mempunyai cakupan yang luas diantaranya yaitu tentang perkawinan, perwalian, perwakafan, wasiat, warisan, hibah, nafkah, dan hadhanah (Amany Lubis; 2018; 13).

Hukum Islam memberikan garisan yang tegas tentang pemeliharaan hak hak manusia yang tertuang dalam adh dharuriyyat al khams, atau al ushul al khamsah (lima dasar yang bersifat penting atau utama). Kelimanya yaitu memelihara agama, memelihara jiwadiri, memelihara akal, memelihara keturunan, dan memelihara harta agar tercipta kebahagiaan hidup dunia dan akhirat.

Dalam rangka mewujudkan kemaslahatan dalam keluarga, hendaknya setiap anggota dalam keluarga mengetahui dan menjalankan masing masing hak dan kewajibannya dengan baik. Jika itu dapat terlaksana, maka kemaslahatan dalam keluarga akan tercapai. Suami sebagai kepala keluarga menjalankan kewajibannya memberi nafkah ke keluarga untuk pemenuhan kebutuhan pokok, dan memberikan kasih sayang dalam membimbing dan melindungi keluarga. Sekalipun dalam masa pandemi dan terkena PHK, suami hendaknya tetap berusaha bekerja agar peran dalam keluarga tidak hilang. Hal yang sama juga dilakukan oleh istri dalam melaksanakan kewajibannya melayai suami dan anak, melindungi harta suami dan menjaga amanah yang diberikan oleh suami dan mendidik anak anak dengan pendidikan yang baik.

Apabila masing masing individu dari anggota keluarga mengetahui tanggung jawabnya, maka besar kemungkinan keluarga akan memiliki kemampuan menghalau hal hal buruk yang menimpa keluarga. Baik secara individu maupun bersama sama dalam keluarga. Termasuk apabila kepala keluarga terkena PHK akibat dampak pandemi Covid-19. 
Daripada itu, dalam membangun keluarga yang kuat, diperlukan tiga komponen utama agar tidak mudah rapuh. Yang pertama adalah ketahanan fisik, ketahanan social, dan ketahanan psikologis.

Ketahanan fisik meliputi kebutuhan primer dalam keluarga. Meliputi kebutuhan sandang, pangan, dan papan, kesehatan, dan pendidikan. Ketahanan social terlihat pada pembagian peran, dukungan untuk maju dan waktu kebersamaan anggota keluarga, membina hubungan social yang baik, dan mekanisme penanggulangan masalah dalam keluarga tersebut. Ketahanan psikologis, adalah kemampuan untuk menanggulangi masalah non fisik dengan melakukan pengendalian emosi secara positif. Hal ini mensyaratkan kepedulian satu sama lain antar anggota keluarga terutama peran suami dan istri.

Dalam penelitian yang dilakukan oleh Muhammad Thariq, komunikasi interpersonal menjadi cara untuk dapat membangun ketahanan keluarga. Komunikasi interpersonal antar anggota keluarga berperan penting membentuk ketahanan keluarga dan menguatkan fungsi keluarga menghadapi tantangan ke depan yang semakin berat. (Thariq, $2017: 34$ ).

Komunikasi interpersonal ditandai dengan komunikasi tatap muka sehingga masing masing pihak membaca mimik muka, bahasa tubuh, hingga belaian atau sentuhan untuk memberikan rasa nyaman dan saling memberi dukungan baiksecara verbal maupun bahasa non verbal satu sama lain. tindakan seperti itu akan menimbulkan perasaan hangat dan sikap supportif dalam menghadapi dinamika dan tantangan dalam keluarga apapun kondisinya, termasuk konflik dan masalah yang timbul dalam rumah tangga karena PHK akibat pandemi Covid-19.

Diperlakukan kesadaran dan latihan untuk mampu mengendalikan diri dan menerima segala kondisi dengan ikhlas. Namun tetap berusaha dan terus berikhtiar untuk mencari solusi dan jalan keluar, usaha diiringi doa, disertai jiwa tawakal berserah diri kepada Allah menjadi sikap hidup yang sangat penting. Memelihara, mengembangkan, dan menguatkan konsep diri perlu terus dibangun, mensyukuri setiap nikmat yang Allah berikan menjadi kata kunci dalam segala keadaan, agar hati menjadi ikhlas dan tenang.

\section{KESIMPULAN}

Dalam masa pandemi Covid-19 yang masih mewabah di Indonesia, membawa berbagai dampak di masyarakat. Mulai dari mobilitas yang terbatasi, hingga yang paling dirasakan adalah Pemutusan Hubungan Kerja (PHK) kepada karyawan sebagai akibat lesunya pasar dan sepi permintaan. PHK bagi karyawan khusunya kepada kepala keluarga tidak hanya berdampak pada individu tersebut saja. Melainkan berdampak lebih luas hingga berpengaruh kepada ketahanan keluarga. 
Nabila Luthvita Rahhma, Anisa Yuniar, Fatimah Qurrotu A'yun, Indri Kurniati, Dania Saferina Ifada

Ketahanan keluarga merupakan factor yang penting dalam mempertahankan keluarga yang sakinah. Ketahanan keluarga merupakan keuletan dan segala upaya keluarga dalam menghadapi segala permasalahan dalam keluarga agar tetap utuh dan tidak berakhir dengan perceraian.

Berdasarkan data dari Mahkamah Agung, angka perceraian selama masa pandemi tidak mengalami kenaikan yang signifikan. Angka perceraian justru menurun pada April, namun ketika penerapan PSBB angka perceraian kembali naik. Meskipun tidak menyumbang kasus perceraian yang disebabkan oleh PHK, namun data tersebut menerangkan bahwa PHK dan factor ekonomi akibat hilangnya pekerjaan berpengaruh terhadap ketahanan keluarga.

Adapun upaya dalam menjaga ketahanan keluarga diperlukan sebagai landasan utama agar keluarga tetap utuh yaitu dengan menerapkan fungsi keluarga sebagaimana mestinya. Hal ini penting sebab kelaurga merupakan tempat pertama bagi anggota keluarga untuk saling berbagi dan mendukung satu sama lain appaun kondisinya. Sehingga, PHK yang dialami oleh anggota keluarga tidak menurunkan semangat untuk mencari pekerjaan lain. Hal yang lain yaitu tetap menjalankan hak dan kewajiban masing masing anggota keluarga, serta menjaga komunikasi interpersonal antar sesama anggota keluarga.

\section{DAFTAR PUSTAKA}

Awaliyah, G., \& Rostanti, Q. (2020). Kasus KDRT Meningkat Selama Pandemi Covid-19. Retrieved April 14.

Hana, K. F. (2020). Keputusan Wanita Muslim Milenial Berwirausaha: Pengaruh Konsep Diri dan Lingkungan. At-Tijaroh: Jurnal Ilmu Manajemen Dan Bisnis Islam, 6(1), 23-36.

Hibana. Meningkatkan Ketahanan Keluarga di Masa Pandemi Corona. http://digilib.uin-suka.ac.id.

Imas Novita Juaningsih. 2020. Analisis Kebijakan PHK bagi Para Pekerja pada Masa Pandemi Covid-19 di Indonesia. Pusat Studi Konstitusi dan Legislasi Nasional (Poskolegnas). Universitas Islam Negeri Syarif Hidayatullah Jakarta. Adalah : Buletin Hukum dan Keadilan. Vol 4 No 1 (2020).

Kompilasi Hukum Islam. Instruksi Presiden Nomer 1 Tahun 1991.

M. Thariq. (2017). Membangun Ketahanan Keluarga Dengan Komunikasi Interpessonal. Simbolika vol 3 (1) April 2017. Univ Muhammadiyah Sumatera Utara FISIP

Moh. Muslim. PHK Pada Masa Pandemi Covid-19. (2020). Esensi : Jurnal Manajemen Bisnis, Vol 23 No.3/2020. Institut Bisnis Nusantara. 
Nurhadi Sucahyo. (2020). Cerai di Masa Pandemi https://www.voaindonesia.com/amp/cerai-di-masa-pandemi-ditahan-psbbdidorong-ekonomi-/5578035.html

Peraturan Pemerintah Nomor 21 tahun 1994 tentang Penyelenggaraan Pembangunan Keluarga Sejahtera

Peraturan Presiden Nomor 36 Tahun 2020 tentang Pengembangan Kompetensi Kerja

Peter Mahmud Marzuki. (2005). Penelitian Hukum. Jakarta: Prenadamedia Group.

Prof. Dr Hj Amany Lubis, MA, dkk. (2018). Ketahanan Keluarga dalam Perspektif Islam. Jakarta: Pustaka Cendikiawan Muda.

Prof. Dr. Ir. Euis Sunarti, M.Si. (2015). Ketahanan Keluarga Indonesia: dari Kebijakan dan Penelitian Menuju Tindakan. Fakultas Ekologi Manusia Institut Pertanian Bogor. Orasi Guru Besar.

Undang undang nomer 10 tahun 1992 tentang perkembangan, kependudukan dan pembangunan keluarga sejahtera

Undang-Undang Nomor 1 Tahun 1974 Tentang Perkawinan

Undang-Undang Nomor 13 Tahun 2003 Tentang Ketenagakerjaan

Uyun, Muhamad. (2020). Ketahanan Keluarga dan Dampak Psikologi dimasa Pandemi Global. https://s3ppi.umy.ac.id. 